\title{
Preventing the Wrongful Criminalization of Online Gender-based Violence Victims: A Look into Law No. 44 of 2008 on Pornography
}

\author{
Almyra Luna Kamilla \\ Faculty of Law, Universitas Gadjah Mada \\ *Penulis Koresponden: almyralk@gmail.com
}

\section{ABSTRAK}

Undang-Undang No. 44 Tahun 2008 tentang Pornografi secara eksplisit melarang keras pembuatan konten yang mengandung pornografi, namun disisi lain, Penjelasan Pasal 4 ayat (1) pada Undang-Undang tersebut secara implisit memberikan hak bagi masyarakat untuk membuat materi pornografi selama ditujukan untuk diri sendiri dan demi kepentingan sendiri. Hal ini membuat adanya perdebatan yang dipengaruhi juga oleh nilai-nilai dasar bangsa Indonesia sebagai negara yang beradab dan beragama. Dalam prakteknya, Pasal 4 ayat (1) UU No. 44 Tahun 2008 tidak jarang disalahgunakan untuk menjadikan korban Kekerasan Berbasis Gender Online (KBGO) sebagai tersangka dalam kasus pornografi. Melalui pendekatan feminis dan berorientasi korban, Penelitian ini akan membahas bagaimana UU No. 44 Tahun 2008 tentang Pornografi dimanfaatkan baik sengaja atau tidak sengaja, sebagai senjata dalam reviktimisasi perempuan korban KBGO. Penulis menggunakan pendekatan yuridis-normatif dimana Penelitian ini didasari atas analisa terhadap peraturan perundang-undangan yang berlaku di Indonesia serta studi literatur. Hasil penelitian ini menemukan bahwa pada UU No. 44 Tahun 2008 tentang Pornografi terdapat perbedaan norma yaitu antara Pasal 4 ayat (1) dengan Penjelasan Pasal 4 ayat (1). Selanjutnya, dapat disimpulkan bahwa perbedaan norma tersebut disertai dengan pendekatan penegak hukum di Indonesia yang cenderung konservatif, memicu fenomena dimana korban KBGO yang seharusnya dilindungi justru dikriminalisasi.

Kata Kunci: KBGO; Pornografi; Hak atas Materi Pornografi; Sistem Peradilan Pidana Berorientasi Korban

\section{ABSTRACT}

Law No. 44 of 2008 on Pornography explicitly condemned the creation of pornographic content, on the other hand, the Elucidation of Art. 4 (1) of the Law implicitly grants the right for the people to create pornographic material so long as it is intended for oneself and one's interest. This issue has caused a debate that is also influenced by the fundamental values of Indonesia as a nation that is civilized and religious. In practice, Art. 4 (1) of Law No. 44 of 2008 on Pornography is often misused to cause victims of Online Gender-based Violence into suspects of cases of pornography. Using the feminist approach and victim-oriented perspective, this Research will discuss how Law No. 44 of 2008 on Pornography is utilized, on purpose or otherwise, as a weapon in revictimizing women who are victims of Online Gender-based Violence. The Author used the juridical-normative method in which the Research is constructed based on the analysis of Indonesian laws and regulations as well as literature studies. The results of this Research found that there are contradicting norms within Law No. 44 of 2008 on Pornography specifically between Art. 4 (1) and its Elucidation. Furthermore, it can be concluded that such contradicting norms complemented with the approach of Indonesian law enforcers which tends to be conservative, precipitated a phenomenon in which victims of Online Gender-based Violence who are supposed to be protected ended up criminalized.

Kata Kunci: Online Gender-based Violence; Pornography; Right over Pornographic Materials; Victim-Oriented Criminal Justice System

\section{INTRODUCTION}

The Indonesian National Commission on Violence against Women ('Komnas Perempuan') on their Annual Report of 2021 stated that during the course of the year 2020 they received 940 reports on cases of Online Gender-based Violence which took a significant escalation compared to the number of cases reported in the year 2019 which is 241 in total (Komnas Perempuan, 2021). 
During the COVID-19 Pandemic, human mobilization have been minimized like never before, in an era where technology is capable of accomodating almost all aspects of our lives, the platform on which sexual violence against women occurs, have also migrated to the online sphere which also make sexual violence cases more common, harder to define, and harder to trace.

The matter of pornography is no stranger to the online sphere, since the development of the internet, pornography has spreaded around the globe through many online platforms. Indonesia as a country that is proud of its cultural and religious values have established several law as a sword in combating pornography. The notion is supported by the enactment of Law No. 11 of 2008 on Electronic Information and Transactions which contains several provisions condemning the distribution, transmission, and/or accessibility of Electronic Information and/or Electronic Records with contents against propriety (decency), furthermore, the State's effort in combating pornography is most evident by the enactment of Law No. 44 of 2008 on Pornography ('Law on Pornography') which intensely condemned the people from producing, creating, multiplying, duplicating, distributing, broadcasting, importing, exporting, offering, trading, renting, and providing materials which contains pornography.

Although the act of creating pornography is forbidden pursuant to Art. 4 (1), the Elucidation of Art. 4 (1) gives way for the people to create pornography for themselves and for their own private interest, this formal recognition of the right to create pornographic material for private use herein after referred to as the right over pornographic material. In a state that is rooted to its culture and the people's religious values, the existence of the right over pornographic material causes a problem in the implementation of the Law on Pornography, this is because on one hand, the law condemns the creation of pornographic materials, and on the other hand it allows such materials to be created for private use, taken into account the people's (including legal enforcers') personal values and beliefs, the existence of the right over pornographic material causes a troublesome conundrum, which in more than one occasion, have caused the wrongful criminalization of women who are supposedly victims of Online Gender-based Violence. Therefore, through this particular research, the Author would try to analyze the existence of the right over pornographic materials from a feminist point of view under the contextualization of Pancasila and the 1945 Constitution, and analyze the influence of the Law on Pornography on the wrongful criminalization of Online Gender-based Violence victims with the pure intent of providing justice to such victims because as John Stoltenberg stated: Sexual freedom must be accompanied by sexual justice.

\section{LITERATURE REVIEW}

\section{Definition of Pornography}

From a historical perspective, the word 'pornography' comes from the Greek word porni or porne which is defined as female sex slaves, or in a relatively modern term: prostitutes, as well as the word graphos which means writing or depiction of the life of prostitutes (Jenkins). From the feminist perspective, it can be concluded that the origin of the word pornography itself puts women in a position that is rather low (Yatim, 2004:9), hence, many prominent feminist such as Catharine A. MacKinnon and Andrea Dworkin defined pornography as the "graphic sexually explicit subordination of women through pictures and words", they even stipulated pornography as a civil rights violation which entails the 'systematic practice of sexual discrimination that violates women's right to equality' (West, 2004).From the general point of view, pornography is often defined as materials that depicts erotic behavior and is intended to cause sexual excitement 
(Merriam-Webster Dictionary). It is important to note that since pornography is often linked to matters such as moral and obscenity, the definition and the form of pornography often change depending on one's own subjectivity and more importantly: community standards.

For the purpose of this particular research with an intense relevancy on the analysis of the Law on Pornography, the Author would use the word pornography as defined in Art. 1 point 1 of the Law on Pornography which define pornography as "drawing, sketch, illustration, photograph, writing, sound, noise, moving picture, animation, cartoon, conversation, gestures, or other forms of messaging through various forms of communication media and/or public performances containing obscenity or sexual exploitation that violates the norms of decency in society". Under this definition, there are at least three cumulative criteria which will stipulate a material as pornography. The first criteria is the form of pornography itself which can be either drawing, sketch, illustration, photograph, writing, sound, noise, moving picture, animation, cartoon, conversation, gestures, or other form of messages. Second, in order for a material to be considered as pornography, it must fulfill the criteria of publicity, this is because Art. 1 point 1 of the Law on Pornography stipulates pornography as a material that is exhibited through various forms of communication media and/or public performances. As explained by Christianto, the matter of pornographic material does not depend on the amount of people who have witnessed or became aware of such material, but it depends on whether or not such pornography was created with the intention for the public to be aware of it's existence (Christianto, 2015:82). The third criteria is that pornography must contain obscenity or sexual exploitation that violates the norms of decency in society, relatively this is the criteria that is rather difficult to be stipulated seeing that decency, as aforementioned, is a matter that is subjective to one's own understanding and it often changes along with the dynamics of the society. When talking about decency in Indonesia, the teachings of Pancasila must be taken into consideration, and under the teachings of Pancasila, the type of conduct which violates decency constitute as a serious threat to social order especially to the values which is held in society because the matter of decency relates to one's good name and honor (Fajrin, Adhial, and Triwijaya, 2020:162).

\section{Pornography and Online Gender-based Violence}

Online Gender-based Violence or as referred to in Bahasa as Kekerasan Berbasis Gender Online $(K B G O)$ or as Komnas Perempuan often referred to as Kekerasan Berbasis Gender Siber (KBGS) is a form of violence that occurs on the basis of gender relation between the perpetrator and the victim which happens in the online domain or which uses digital technology (Alubaidah, 2021). Komnas Perempuan in their Annual Report of 2021 stipulated several forms of Online Genderbased Violence including:

1. Cyberstalking;

2. Intimidation;

3. Cyber harassment;

4. Harassment in various platform;

5. Assaulting comments;

6. Accessing, uploading, or distributing intimate images, videos, audio clip without consent;

7. Accessing or distributing private data without consent;

8. Doxing; and

9. Sextortion. 
The matter of pornography which is discussed in this research would be the type of cases in which intimate images, videos, audio clip, and other forms of material containing pornography is accessed, uploaded, or distributed without the consent of the women involved. In several instances, this type of Online Gender-based Violence was intended as a form of revenge (often referred to as revenge porn) or as a way of obtaining profit, such occasion happened in Garut in the case of PA (female, 19) whose intimate videos were recorded, uploaded, and sold online by her ex-husband (Komnas Perempuan, 2021).

\section{ANALYSIS}

\section{The Right over Pornographic Materials as Right to Privacy}

When a person decides to create any form of pornographic materials, they open themselves up to chances of being the victim of decency-related crimes as regulated under the Indonesian legal system for instance through provisions contained in the Indonesian Criminal Code, Law No. 11 of 2008 on Electronic Information and Transactions, and lastly provisions contained in the Law on Pornography. However, the Law on Pornography set out a provision that will allow pornographic materials to be created for oneself and one's interest, this can be stipulated from Art. 4 (1) of Law on Pornography which stated that:

Anyone is forbidden to produce, create, multiply, duplicate, distribute, broadcast, import, export, offer, trade, rent, or provide pornography which explicitly contain:

1. Intercourse, including deviant intercourse;

2. Sexual violence;

3. Masturbation;

4. Nudity or impressive display of nudity;

5. Genitalia; or

6. Child Pornography.

The clause above is accompanied by an Elucidation for Art. 4 (1) which includes the phrase "What is meant by 'create' is not included for oneself and one's interests". The Elucidation implicates a right over creating pornographic materials so long as it is created for oneself and one's interest, Christianto used the term 'right over pornographic material' when discussing such right (Christianto, 2015:63). The Indonesian Government when giving their explanation on a judicial review of the Law on Pornography before the Indonesian Constitutional Court dictates that the Elucidation of Art. 4 (1) of the Law on Pornography is a "form of protection of the right to privacy which must be respected and guaranteed", furthermore, the Government consider a violation of the protection of privacy right as dictated under the Elucidation of Art. 4 (1) of the Law on Pornography as a violation of human rights as stipulated under Art. 28G (1) of the 1945 Constitution ${ }^{1}$.

The right to privacy constitute as basic human right which must be recognized, guaranteed, and protected by everyone including through the law and through state practice. Aside from being formally recognized in the 1945 Constitution of the Republic of Indonesia, the right to privacy is globally recognized through Art. 12 of the Universal Declaration of Human Rights (UDHR) and

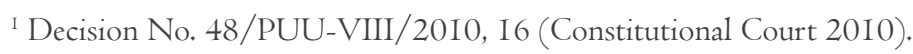


Art. 17 of the International Covenant on Civil and Political Rights (ICCPR). In the international level, the right to privacy is regulated through provisions which stipulate that no one shall be subjected to arbitrary interference with his privacy, family, home, or correspondence, nor to attacks upon his honor and reputation. The right to privacy gives way for people to be who they are and to live a life based on their own choices, Christianto consider the right to privacy to be in a high position as the type of human rights that is entitled individually to every human and its existence shall not be intervened (Christianto, 2015:77).

When talking about the right to privacy, and to an extent: human rights, it is crucial to remember that despite its universality, according to Satjipto Rahardjo, the implementation of human rights differ from one country to another, it must be adjusted with the history, social condition, economy, and culture of a nation (Triputra, 2017:292). In the Indonesian context, the recognition and protection of human rights must be in line with the country's history, socio-economic, and cultural background, thus the most appropriate framework is to implement the recognition and protection of human rights under the perspective of Pancasila and the 1945 Constitution, in simple words, Pancasila and the 1945 Constitution is utilized as a tool for contextualization. On the matter of such contextualization, Christianto opined that there shall not be any problem in the recognition and protection of human rights when contextualized under the values of Pancasila because Indonesia has long uphold human civilization as a fundamental value of the nation (Christianto, 2015:86).

The Influence of Law No. 40 of 2008 on Pornography on the Wrongful Criminalization of Online Gender-based Violence Victims

On December 2020, the Greater Jakarta Metropolitan Regional Police confirmed GA, a female celebrity, and her partner MYD as suspects in the case of pornography, the two are accused of having violated Art. 4 (1) jo Art. 29 of the Law on Pornography after an intimate video of them (with a duration of 19 seconds) spread around the internet (Kompas, 2020). The case have caused some controversy within the Indonesian society, the Institute for Criminal Justice Reform (ICJR) as well as Komnas Perempuan are known to have said that from the facts of the case, it appears that GA is actually the victim of non-consensual distribution of intimate video (Santoso and Ardiansyah, 2020). Such a notion is supported under the Elucidation of Art. 4 (1) of the Law on Pornography which allows the creation of pornographic material so long as it is created for oneself and for one's interest, from what is known about the case, neither GA nor MYD have the intention to distribute the video to the eye of the public, neither do they have any commercial-related intention. In strictly implementing the provisions of the Law on Pornography which recognize the right over pornographic material, the police as the investigator should put a focal point on the perpetrator who have arbitrarily published and distributed the video into the online platform. Similar to the case of GA, in the aforementioned case happening in Garut, PA is accused of having violated Art. 4 (1) of the Law on Pornography, however, from the facts of the case, it is concluded that when giving her consent to create the intimate video, her ex-husband claimed that the video is created for their own interest, therefore, PA did not have the intention for this video to be known to the eyes of the public (Priyasmoro, 2020), thus, her case falls under the Elucidation of Art. 4 (1) of the Law on Pornography, and appointing PA as a suspect would constitute revictimization since she's already a victim of Online Gender-based Violence in the first place.

The case of GA and PA are two out of many cases in which victims of Online Gender-based Violence specifically related to the non-consensual distribution of pornographic material had been 
wrongfully criminalized under Art. 4 (1) of the Law on Pornography. The Elucidation of the aforementioned article has indeed explicitly recognized the right over pornographic materials for private use, however, in implementing such law, law enforcers are often focused on their own interpretation of the law. This unfortunate situation may be caused by the fact that the Elucidation of Art. 4 (1) offers a different norm than the phrase of Art. 4 (1) itself. According to the Concurring Opinion of Constitutional Court Judge Maria Farida Indrati when faced with a judicial review on the Law on Pornography, she noticed that there exist a conflicting meaning between the norms of Art. 4 (1) and its Elucidation, therefore, such contradiction could result in the lack of legal certainty, she even went as far as saying that Art. 4 (1) of the Law on Pornography and its elucidation is not in accordance with the principles of legislative drafting specifically the principle of 'clarity of formulation' and the principle of 'legal order and certainty' as stipulated under Art. 5 point $f$ and Art. 6 (1) of Law No. 10 of 2004 on the Formulation of Laws and Regulations ${ }^{2}$. The contradiction between Art. 4 (1) and its Elucidation is very unfortunate considering that the law should have provided a clear framework as to what's allowed and what's not allowed when it comes to the creation of pornographic materials.

Having acknowledged such contradicting norms, it must be taken into account that the Constitutional Court declined the request of the petitioner in Decision No. 48/PUU-VII/2010 which claimed that the Elucidation of Art. 4 (1) and the Elucidation of Art. 6 of the Law on Pornography contradicts consitutional rights as guaranteed under Art. 28D (1), 28J (1) and (2), and Art. 29 (1) of the 1945 Constitution. Based on the Decision of the Constitutional Court, the Elucidation of Art. 4 (1) is Constitutional under the consideration that any form of pornographic materials which are created for oneself and for one's interest does not violate the principle of decency, nor does it disturb public order because it is created for private purposes, not for the eye of the public ${ }^{3}$. Therefore, in handling cases of alleged violations of Art. 4 (1) of the Law on Pornography, law enforcers must take into account the original intent of the parties involved in regards to the use of the pornographic material, wheter it is created for private use or for public and/or commercial purposes. Law enforcers must also take into account whether or not the women involved have any knowledge regarding: 1) the creation of such pornographic material; 2) whether she gave consent or not, and; 3) if she indeed gave her consent, was she aware of her partner's private or public intent in creating such materials. Moreover, law enforcers and legislator must be aware of the fact that the Law on Pornography is not victim-oriented, especially to women who are victims of Online Gender-based Violence. In handling cases related to pornography, related parties such as the police, public prosecutors, and judges must take into account the fact that the creation of pornographic material may generate violence against women. According to Jurnal Perempuan's analysis on the Anti-Pornography and Anti-Pornoaction Bill, violence against women might be inflicted since the beginning until the end of the production of pornographic materials, the scenarios are listed below:

1. During the beginning of production: Possibility of coercion, seduction, and the lure of women to become objects of pornography

2. During the creation of pornographic material: Physical exploitation

\footnotetext{
${ }^{2}$ Decision No. 48/PUU-VIII/20I0, 3 I (Constitutional Court 20I0).
}

${ }^{3}$ Decision No. 48/PUU-VIII/20I0, 25 (Constitutional Court 20I0). 
3. During and/or after the dissemination of pornographic material: The loss of women's physical integrity

4. After-effect: Sexual violence against women who are objects of pornography or other women in general, in the form of rape, assault, etc (Jurnal Perempuan, 2004:5).

\section{CONCLUSION AND RECOMMENDATION}

\section{Conclusion}

Robin Morgan stated that "Pornography is the theory, and rape is the practice". From a feminist perspective, the problem with pornography is not the indulgence of sexuality itself but it's how women's dignity are undermined through the sexual objectification of women (Yatim, 2004:9). When handling cases of pornography, it is important to remember that women are more than just their body, they are more than just sexual objects. The objectification of women would not exist if we also recognized the fact that women are not just their bodies, they are also defined by their minds and spiritual beings. Elucidation of Art. 4 (1) of the Law No. 40 of 2008 on Pornography formally recognize the right over pornographic materials which allows the creation of pornographic content for oneself and for one's interest, seeing that this right constitute as a right to privacy which is classified as basic human rights as dictated by both national and international legal instruments, the right over pornographic materials shall be recognized and protected when implementing the Law on Pornography. Having recognized the contradicting norms between Art. 4 (1) of the Law on Pornography and its Elucidation, so long as the law has not ben amended or declared inconstitutional, it is important for the people as well as the state to formally respect the right over pornographic materials, and such consideration must be taken into account when handling cases of pornography, especially those related to the non-consensual distribution of pornographic materials.

\section{Recommendation}

Based on the analysis provided above, listed below are several policy recommendations given by the Author:

1. The Government of Indonesia i.e. related law enforcers and legislators and the citizens of Indonesia must recognize that there are indeed contradicting norms between Art. 4 (1) of the Law on Pornography and its Elucidation, one which forbids the creation of pornographic material and one which allows such thing so long as it is made for oneself and for one's interest. This contradiction has lessened the degree of legal certainty offered by the Law on Pornography where parties who have created pornographic materials ended up being the suspects alleged of having violated Art. 4 (1) of the Law on Pornography. The citizen can partake in ensuring that the law offer legal certainty to its maximum capacity through active participation either through requesting judicial review to the Constitutional Court or simply by helping civil society to raise awareness regarding the double-edged sword that is the Law on Pornography.

2. Legal enforcers in handling cases of violations of Art. 4 (1) of the Law on Pornography must use the victim-oriented approach. In criminalizing a suspect, legal enforcers must truly consider the original intent and the relation between the parties involved in creating 
pornographic materials because more often than not, women are either forced to participate in the creation of pornographic materials, or they have zero knowledge of the fact that such materials were intended to be distributed into the public sphere. By providing a more comprehensive sensitivity to the condition of the victim, law enforcers would have a lesser chance of making them poor targets of revictimization.

3. Related to a system that is victim-oriented, the Government must consider establishing a criminal justice system that is relatively progressive and is more sensitive towards the condition of victims of Online Gender-based Violence, this could be done by creating regulations or policies which will provide psychosocial and/or medical assessment for victims of Online Gender-based Violence, the Government could also take a more active role in ensuring the eradication of traces of pornographic materials spreaded out in the online sphere as well as ensuring that the criminal justice system not only provide adequate punishments for perpetrators, but also provide a mechanism that is rehabilitative not only for the victims but also for the perpetrators.

\section{BIBLIOGRAPHY}

\section{Laws and Court Decisions}

The 1945 Constitution of the Republic of Indonesia

Decision of the Constitutional Court of the Republic of Indonesia No. 48/PUU-VII/2010

Journals

Anon, 2004. Catatan Kritis Atas RUU Anti Pornografi Dan Anti Pornoaksi. Jurnal Perempuan: Pornografi, (38), p.45.

Christianto, H., 2015. Eksistensi Hak Atas Pornografi Berdasarkan Norma Kesusilaan. Veritas Et Justitia: Jurnal Ilmu Hukum, 1(1), p.61.

Fajrin, Y.A. \& Triwijaya, A.F., 2020. Problematika Yuridis dan Konsep Rekonstruksi terhadap Inkonsistensi Norma Undang-Undang Pornografi. Jurnal Wawasan Yuridika, 4(2), p.149.

Triputra, Y.A., 2017. Implementasi Nilai-Nilai HAM Global Ke dalam Sistem Hukum Indonesia yang Berlandaskan Pancasila. Jurnal Hukum IUS QUIA IUSTUM, 24(2), pp.279-300.

Yatim, D.H., 2004. Mengurai Fenomena (Perempuan Dan) Pornografi. Jurnal Perempuan: Pornografi, (38), p.9.

\section{Online Articles}

Alubaidah, M.T., 2021. Kekerasan Berbasis Gender Online (KBGO). Kumparan. Available at: https://kumparan.com/mohammadtetraalubaidah/kekerasan-berbasis-gender-online-kbgo1v16FRfXjzk [Accessed March 23, 2021].

Anon, Pornography. Merriam-Webster Dictionary. Available at: https://www.merriamwebster.com/dictionary/pornography [Accessed March 23, 2021].

Bustomi, M.I. \& Sari, N., 2020. Ini Alasan Polisi Tetapkan Gisel Sebagai Tersangka Kasus Video Syur. 
https://megapolitan.kompas.com/read/2020/12/31/21430851/ini-alasan-polisi-tetapkangisel-sebagai-tersangka-kasus-video-syur?page=all [Accessed March 26, 2021].

Jenkins, J.P., Pornography. Encyclopcedia Britannica. Available at: https://www.britannica.com/topic/pornography [Accessed March 23, 2021].

Priyasmoro, M.R., 2020. ICJR Ingin Perempuan Pemeran Pornografi Garut Dibebaskan, Ini Alasannya. Liputan6.com. Available at: https://www.liputan6.com/news/read/4346726/icjringin-perempuan-pemeran-pornografi-garut-dibebaskan-ini-alasannya [Accessed March 26, 2021].

Santoso, B. \& Ardiansyah, N., 2020. Komnas Perempuan Soroti Kasus Video Syur Mirip Gisel: GA Cuma Korban. Suara.com. Available at: https://www.suara.com/news/2020/12/30/110317/komnas-perempuan-soroti-kasus-videosyur-mirip-gisel-ga-cuma-korban. [Accessed March 26, 2021].

West, C., 2004. Pornography and Censorship. Stanford Encyclopedia of Philosophy. Available at: https://plato.stanford.edu/entries/pornography-censorship/\#WhaPor [Accessed March 23, 2021].

Official Reports

Komnas Perempuan, 2021. CATAHU 2021: Catatan Tahunan Kekerasan Terhadap Perempuan Tahun 2021. Available at: https://komnasperempuan.go.id/catatan-tahunan-detail/perempuandalam-himpitan-pandemi-lonjakan-kekerasan-seksual-kekerasan-siber-perkawinan-anak-danketerbatasan-penanganan-di-tengah-covid-19-catahu-2021-catatan-tahunan-kekerasan-terhadapperempuan-tahun-2020 [Accessed March 23, 2021]. 